\title{
The JOURneY OF Christianity to INDiA
}

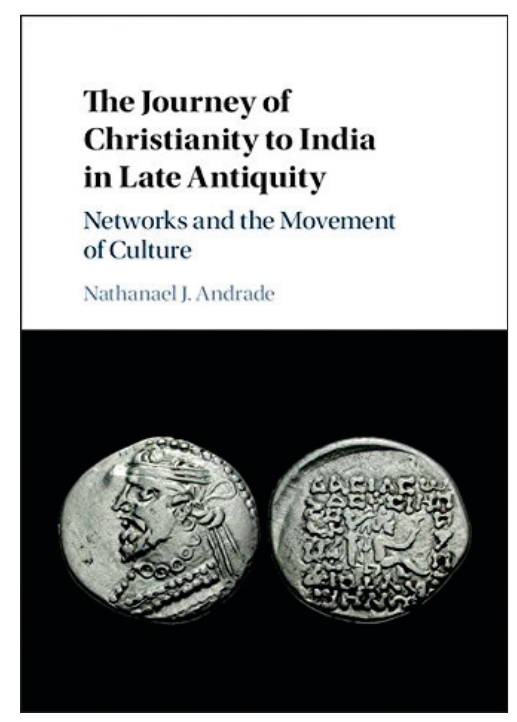

ANDRADE, NATHANAEL J. (2018). The Journey of Christianity to India in Late Antiquity. Networks and the Movement of Culture. Cambridge: Cambridge University Press. 312 pp., 64,46€ [ISBN 978-1-1082-9695-3].

\author{
MARIANNA FERRARA \\ SAPIENZA UNIVERSITÀ DI ROMA \\ MARIANNA.FERRARA@UNIROMA1.IT
}

"How did Christianity make its Remarkable voyage from the Roman Mediterranean to the Indian subcontinent?". This question represents the core of the book by Nathanael J. Andrade, associate professor in the Department of History at State University of New York, Binghamton. Andrade immediately answers in the subtitle of the book: "Networks and the Movement of Culture". Indeed, Andrade's volume, The Journey of Christianity to India in Late Antiquity, deals with networks, commercial roots, connections, circulation of people, objects, and ideas. All these interesting themes introduce the reader to the thematic of how the religious history of South Asia was connected to that of the Mediterranean in late Antiquity through the Christian narratives about the apostle "Judas Thomas". Andrade's methodological choice of using 
the double name "Judas Thomas" provides the reader with the first clues about his methodological approach to the issue under study, by giving equal attention to the Syriac and Greek versions of the so-called Acts of Thomas. At the same time, a methodological perspective that focuses on connections allows the author to show how late antique economy opened the way to the eastward travel of Christianity and how the movements of cultures followed suit.

Readers will find in this book an original study of the global history of Christianity in late Antiquity that privileges the vital role of Greek sources of the so-called "Thomasine" literature over the Syriac tradition due of their connecting function. The main hypothesis behind this is that "the surviving Greek versions often preserve readings close to the original composition (whatever its language) than the surviving Syriac tradition" (p. 29). Such a premise recurs in the first part (chap. 1. "The Acts of Thomas and Its Impact", pp. 27-66), in Andrade's discussion of the arguments about the origin of the composition of the so-called Acts of Thomas, available in the Greek and Syriac languages. Although Andrade brings new evidence to the discussion (such as the Greek Syriac terms for "silver" - through the Middle Persian and the Hebrew languages - in the episode of the purchase of Judas Thomas, and the words to name general Siphor), it remains hard to prove the textual primacy of one version of the Acts of Thomas over another. Andrade questions the provenance of the Acts of Thomas outside the Roman Near East and illustrates the complexity of the cultural milieu in which this text had originated before reaching the final version known to modern scholars. In his reconstruction, Andrade outlines a cosmopolite and intellectual milieu between Upper Mesopotamia and the Persian Gulf, which does not necessarily overlap with India, thus disputing the Thomasine narratives claim that India is the location of Thomas' overseas ministry and martyrdom.

Interestingly, Andrade calls attention to the Manichaean and Zoroastrian "resonances" and attempts to reconstruct both the cultural network through which Christian narratives moved in order to account for Judas Thomas' preaching in Parthia and North India. He also endeavours to locate commercial routes and key transit points, involving the different names for ports, cities, and islands in the Greek, Syriac, Latin, and Arabic sources, in order to reconstruct the travel from Jerusalem to India (the "south land") through the Persian Gulf in the $2^{\text {nd }}$ and $3^{\text {rd }}$ cent. CE. More specifically, Andrade suggests the possibility that the episode of Judas Thomas' sea travel from Jerusalem to India might have unravelled along the lines of "a nautical voyage from the Persian Gulf to Bahrein or Kharg and then the subcontinent" (p. 50). Andrade considers this factor to hold that the Acts of Thomas contain pre-existing materials and have limited historical value. As a historian of religions, however, the present reviewer considers such an idea to be crucial in the attempt to illustrate 
the cultural network Andrade intends to reconstruct. Indeed, Andrade's efforts to show the impact of the Parthian and Indian trajectories of Acts of Thomas (pp. 50-54) provide a relevant research direction which would allow us to rethink the beliefs and textual practices of late antique Christians about the West, Central and South Asia.

The second part of the book, titled "Christianity, Networks, and the Red Sea," focuses on the "Early Christianity and Its Many Indias" (chap. 2, pp. 69-93) and on "The Roman Egyptian Network, the Red Sea, and the Indian Ocean" (chap. 3, pp. 94-136). Although economics provides the framework to reconstruct the connections and the routes for circulation between the Roman Egyptian network and the Red Sea, Andrade does not consider trade as the driving force for Christian preachers. Indeed, he does not seem interested in describing the economic network between the Mediterranean and the Indian Ocean. Instead, Andrade tries to understand how geographical knowledge and the use of commercial routes and financial practices may have contributed to the late antique knowledge about India and the Indians among the Christian authors. Such a perspective allows the reader to visualise the key position of Arabia and Ethiopia (and their inhabitants) in the movement of Christians from Roman Egypt to the Indian mainland. As Andrade illustrates, the conflation of India and Ethiopia in the geographical knowledge of the times, together with the loss of a direct connection between Roman Egypt and the territories of the Indian Ocean in the $4^{\text {th }}$ cent. CE, are two crucial factors in establishing the reliability of the information. In some cases, the late antique authors' misunderstanding is evident to us. "Romans increasingly used the term "Indian" for any population whose merchants were involved in trade" (p. 74). Most of Indians who are mentioned in $4^{\text {th }}$-cent. CE Christian sources were probably either Ethiopians or Arabians. In the best-case scenario, they could have been either the inhabitants of the island of Taprobane, which is generally taken to be ancient Ceylon, or possibly also Socotra or, it should be added, Sumatra ${ }^{1}$. Andrade supports his research on sources from the $4^{\text {th }}-6^{\text {th }}$ cent. CE, such as a wide range of Christian authors (Rufinus, Socrates, Sozomen, Philostorgius, Jerome), but also on the Latin Exposition of the Entire World, the Greek Itinerary from Eden, and the Letter Regarding the People of India and the Brahmins. He founds evidence that the narratives about the diffusion of Christianity in India are often based on a mislocation: "India" was a literary misnomer for South Arabia or Nubian or Aksumite Ethiopia.

What about the stories about Pantaenus and Bartholomew in India? Andrade is clear on this point: many stories about the diffusion of Christianity in India might have been occurred elsewhere, outside India. However, such sources still

1. Cf. Paris, 1951. 
have historical value about how the "Western Christians" imagined the "Eastern Christians" and through which commercial lines the former arrived at latter. From the point of view of this reviewer, the above-delineated perspective represents the most original contribution of the book and deserves close attention. Andrade deals with it in Chapter 3, where he traces the movement of Christianity from Red Sea Egypt to "India" as it was imagined before $500 \mathrm{CE}$. In an article published in 1958, Paolo Daffinà (unfortunately, a bibliographical reference missing in this book) ${ }^{2}$ noticed that eastward expansion of Christianity was partly due to the lack of significant obstacles and partly to the efficient organisation of the roads of the Parthian empire. Although the Roman empire had no rival in the organisation, the Parthian empire and the Indo-Parthian states favoured the flourishing of caravan cities and commercial and cultural trades. Here, through the networks stretching from Alexandria to the Indian Ocean, the Greek language played a significant role in the intellectual milieu, being familiar to kings, artists, and diplomacy. Moreover, several Jewish colonies settled along the way, playing a crucial role in Roman trade. Andrade brings new insights to previous scholarship on Roman trade with his discussion of the "circulation society" involved in the distribution and the key transit points between Alexandria, the Red Sea ports, and the Indian Ocean, that is "merchants and residents from various empires and realms of India" (p. 101).

The bibliography for archaeological evidence is extensive, but Andrade's arguments are mainly based on the most recent works by the archaeologists and historians Steven Sidebotham and Raoul McLaughlin, who have widely investigated the economic importance of Rome's distant trade. Andrade tries to involve in his research the role of yavanas - as this term appears in Sanskrit and Prakrit inscriptions - in the commercial network. Without an adequate Indological bibliography, however, it is a subject difficult to deal. Andrade refers to a selection of palaeographical examples from Buddhist milieu, but he does not find enough data to distinguish the Greek Yavanas from the foreign Yavanas. Probably, the studies by Klaus Karttunen, Johannes Bronkhorst, and Giovanni Verardi on Indo-Greeks and their relationship with Buddhism would have strengthened Andrade's claims. His volume is relevant, however, in its attempt to outline the "circulation society" in the many Indias involved in the commercial networks from the Mediterranean to the Indian Ocean during the first three centuries CE. This is especially true when the connections between the Roman Egyptian network and South Asian trades had increasingly become indirect, with the consequence that the term "Indian" acquired an increased polysemy.

2. Daffinà, 1958. 
The third part of the book returns to Christianity but focuses on the Persian side of the socio-economic network in order to reassess the movement of Christianity. Andrade illustrates the impact of the Christian literature on standard scholarship about the arrival of Christianity in the eastern countries. He takes into account the unreliability of data about the presence of Christian communities in central Asia before $350 \mathrm{CE}$ (chap. 4. "The Movement of Christianity into Sasanian Persia: Perspectives and Sources", pp. 139-163), while casting light on the intermediary actors between the Western Christians and the Parthian and Sasanian territories (chap. 5. "Social Connectivity between the Roman Levant, Persian Gulf, and Central Asia”, pp. 164-206). The last chapter, "The Late Antique Impact of the Acts of Thomas and Christian Communities in India" (pp. 207-232), returns to the opening question about how the Christianity travelled to India in the first four centuries CE. Data about the Christian communities settled in India are historically provable after $500 \mathrm{CE}$ under the activity of Sasanian merchants. Therefore, according to Andrade, the narratives (both oral and written) about the apostle Thomas circulated after the establishment of the Church of the East. In this chapter, Andrade provides relevant scholarship to understand the diffusion of Christianity in India before $500 \mathrm{CE}$ and to rethink the development from Late Antique to early modern time. Andrade's effort to cast light on the intermediaries (Sasanian Persians) who were "responsible for transporting knowledge of their [Indian Christians] existence to Christian of Mediterranean" deserves attention (p. 213).

To conclude, Andrade's volume, The Journey of Christianity to India in Late Antiquity, provides a precious perspective for the reconstruction of the arrival of Christianity in India at the beginning of common era. It provides a reference framework for Indologists, historians of religions, and historians of Christianity who are interested in the cultural milieu through which Christian narratives about the apostle Thomas started to circulate from Arabia to India and from South Asia to the Mediterranean. It also offers an original investigation about the socio-economic network which favoured such a circulation. For this purpose, Andrade's sources range from Greek, Latin, and Syriac to Middle Persian texts, with some incursions into Sanskrit, Prakrit, Arabic, Pahlavi, and Hebrew. Readers will find in this book two highly appreciated appendixes which provide the beginning of Syriac Acts of Thomas (ed. Wright) and of that of Greek version (ed. Bonnet). An extensive bibliography closes the volume, providing an update selection of distinguished scholarship. 


\section{BIBLIOGRAPHY}

Daffinà, P. (1958). The Early Spread of Christianity in India. An Old Problem Reexamined. East and West, 9.3, pp. 187-191.

Paris, P. (1951). Note sur deux passages de Strabon et de Pline. Journal Asiatique, 239, pp. 13-27.

ARYS, 18, 2020 [377-382] ISSN 1575-166x 